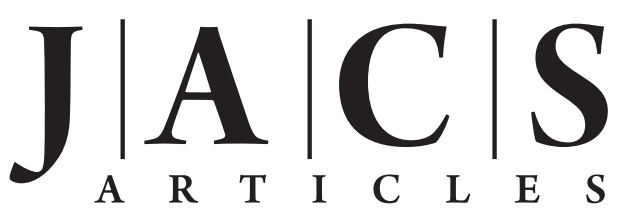

Published on Web 09/09/2010

\title{
Oxygen Reduction Catalyzed by a Fluorinated Tetraphenylporphyrin Free Base at Liquid/Liquid Interfaces
}

\author{
Imren Hatay, ${ }^{\dagger, \ddagger}$ Bin Su, ${ }^{\dagger}, \|$ Manuel A. Méndez, ${ }^{\dagger}$ Clémence Corminboeuf, ${ }^{\S}$ \\ Tony Khoury, ${ }^{\perp}$ Claude P. Gros, ${ }^{\perp}$ Mélanie Bourdillon, ${ }^{\perp}$ Michel Meyer,${ }^{\perp}$ \\ Jean-Michel Barbe, ${ }^{\perp}$ Mustafa Ersoz, ${ }^{\ddagger}$ Stanislav Záliš, ${ }^{, 7}$ Zdeněk Samec, ${ }^{\natural}$ and \\ Hubert H. Girault ${ }^{\star, \dagger}$ \\ Laboratoire d'Electrochimie Physique et Analytique, Ecole Polytechnique Fédérale de Lausanne, \\ Station 6, CH-1015 Lausanne, Switzerland, Department of Chemistry, Selcuk University, \\ 42031 Konya, Turkey, Laboratory for Computational Molecular Design, Ecole Polytechnique \\ Fédérale de Lausanne, BCH-5312, CH-1015 Lausanne, Switzerland, Institut de Chimie \\ Moléculaire de l'Université de Bourgogne, ICMUB (UMR 5260 du CNRS), 9 avenue Alain \\ Savary, BP 47870, 21078 Dijon Cedex, France, and J. Heyrovský Institute of Physical \\ Chemistry of ASCR, v.v.i, Dolejškova 3, 18223 Prague 8, Czech Republic
}

Received April 23, 2010; E-mail: hubert.girault@epfl.ch

\begin{abstract}
The diprotonated form of a fluorinated free base porphyrin, namely 5-( $p$-aminophenyl)-10,15,20tris(pentafluorophenyl)porphyrin $\left(\mathrm{H}_{2} \mathrm{FAP}\right)$, can catalyze the reduction of oxygen by a weak electron donor, namely ferrocene $(\mathrm{Fc})$. At a water/1,2-dichloroethane interface, the interfacial formation of $\mathrm{H}_{4} \mathrm{FAP}^{2+}$ is observed by UV-vis spectroscopy and ion-transfer voltammetry, due to the double protonation of $\mathrm{H}_{2} \mathrm{FAP}$ at the imino nitrogen atoms in the tetrapyrrole ring. $\mathrm{H}_{4} \mathrm{FAP}^{2+}$ is shown to bind oxygen, and the complex in the organic phase can easily be reduced by Fc to produce hydrogen peroxide as studied by two-phase reactions with the Galvani potential difference between the two phases being controlled by the partition of a common ion. Spectrophotometric measurements performed in 1,2-dichloroethane solutions clearly evidence that reduction of oxygen by $\mathrm{Fc}$ catalyzed by $\mathrm{H}_{4} \mathrm{FAP}^{2+}$ only occurs in the presence of the tetrakis(pentafluorophenyl)borate $\left(\mathrm{TB}^{-}\right.$) counteranion in the organic phase. Finally, ab initio computations support the catalytic activation of $\mathrm{H}_{4} \mathrm{FAP}^{2+}$ on oxygen.
\end{abstract}

\section{Introduction}

Molecular oxygen $\left(\mathrm{O}_{2}\right)$ reduction reaction (ORR) maintains the life of an aerobic organism by the respiration process. ${ }^{1-5}$ Owing to the inertness of $\mathrm{O}_{2}$ arising from its low affinity for proton and its triplet electronic state, biological ORR requires catalysis for energy metabolism. Various classes of membranebound enzymes called terminal oxidases that perform this catalytic task, e.g. cytochrome $c$ oxidases, have naturally

\footnotetext{
${ }^{\dagger}$ Laboratoire d’Electrochimie Physique et Analytique, Ecole Polytech-
} nique Fédérale de Lausanne.

\# Department of Chemistry, Selcuk University.

${ }^{\S}$ Laboratory for Computational Molecular Design, Ecole Polytechnique Fédérale de Lausanne.

${ }^{\perp}$ Institut de Chimie Moléculaire de l'Université de Bourgogne, ICMUB (UMR 5260 du CNRS).

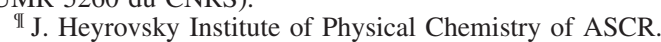

"Present address: Institute of Microanalytical Systems, Department of Chemistry, Zhejiang University, 310058 Hangzhou, China.

(1) Boulatov, R. In $N_{4}$-Macrocyclic Metal Complexes; Zagal, J. H., Bedioui, F., Dodelet, J.-P., Eds.; Springer: New York, 2006, pp 136.

(2) Zagal, J. H.; Paez, M. A.; Silva, J. F. In $N_{4}$-Macrocyclic Metal Complexes; Zagal, J. H., Bedioui, F., Dodelet, J.-P., Eds.; Springer: New York, 2006; pp 41-75.

(3) Collman, J. P. Acc. Chem. Res. 1977, 10, 265-272.

(4) Collman, J. P.; Boulatov, R.; Sunderland, C. J. In The Porphyrin Handbook; Kadish, K. M., Smith, K. M., Guilard, R., Eds.; Academic Press: San Diego, 2003; Vol. 11, pp 1-49.

(5) Collman, J. P.; Boulatov, R.; Sunderland, C. J.; Fu, L. Chem. Rev. 2004, 104, 561-588. evolved. ${ }^{1}$ All of them contain a binuclear heme-Cu catalytic site at which $\mathrm{O}_{2}$ is reduced by forming a ferriheme/superoxide intermediate. This biological pathway has stimulated a significant effort to synthesize biomimetic analogues, e.g. various metalloporphyrins, for better understanding the structure/activity relationship at the catalytic site and developing useful catalysts for energy conversion processes such as $\mathrm{O}_{2}$ reduction in fuel cells. ${ }^{1-6}$ Electrocatalytic $\mathrm{O}_{2}$ reduction by metalloporphyrins has been mostly studied by deposition of metalloporphyrins on an electrode surface, but the deposition methods often induce morphological heterogeneities, making quantitative analyses rather difficult. Alternatively, Fukuzumi et al. have proposed a homogeneous pathway by replacing the electrode with a molecular electron donor, such as ferrocene compounds. ${ }^{7-9}$ In this case, the ferrocene compounds function as electron donors like physiological electron carriers such as quinols in the case of oxidases. The presence of metalloporphyrin catalysts significantly accelerates the $\mathrm{O}_{2}$ reduction by the molecular electron donors. $^{7-9}$

$\mathrm{O}_{2}$ reduction by molecular electron donors has been studied at the interface between two immiscible electrolyte solutions

(6) Collman, J. P.; Fu, L. Acc. Chem. Res. 1999, 32, 455-463.

(7) Fukuzumi, S.; Mochizuki, S.; Tanaka, T. Chem. Lett. 1989, 27-30.

(8) Fukuzumi, S.; Mochizuki, S.; Tanaka, T. Inorg. Chem. 1989, 28, 24592465.

(9) Fukuzumi, S.; Okamoto, K.; Gros, C. P.; Guilard, R. J. Am. Chem. Soc. 2004, 126, 10441-10449. 
(ITIES). ${ }^{10-19}$ This inherently soft interface has been characterized to be sharp at the molecular level with some corrugations or so-called fingerings. The separation of ORR products is also largely favored by the heterogeneous nature of this interface. It has been shown recently that the interface can function as a proton pump driven by the interfacial Galvani potential difference for the $\mathrm{O}_{2}$ reduction by decamethylferrocene (DMFc) to produce hydrogen peroxide $\left(\mathrm{H}_{2} \mathrm{O}_{2}\right){ }^{16}$ Various catalysts including in situ deposited platinum particles ${ }^{20}$ and cobalt porphyrins have been characterized by voltammetric studies. ${ }^{14,15,17,19}$ More surprisingly, it was found also by voltammetric measurements that the protonated forms of free base tetraphenylporphyrin $\left(\mathrm{H}_{3} \mathrm{TPP}^{+}\right.$and $\left.\mathrm{H}_{4} \mathrm{TPP}^{2+}\right)$ could also facilitate $\mathrm{O}_{2}$ reduction by DMFc. ${ }^{18}$ Since, in fact, organic acids such dodecylanilinium can catalyze $\mathrm{O}_{2}$ reduction by DMFc as recently demonstrated, ${ }^{21}$ the role of $\mathrm{H}_{2}$ TPP was not clear, acting simply as an acid or activating molecular oxygen.

Here, we have synthesized a fluorinated free base porphyrin, namely 5-( $p$-aminophenyl)-10,15,20-tris(pentafluorophenyl)porphyrin $\left(\mathrm{H}_{2} \mathrm{FAP}\right)$ that combines a lipophilicity suitable to be investigated by ion transfer voltammetry, and a fluorination of three phenyl rings to ensure a strong electron-withdrawing effect to provide a weak basicity to the tetrapyrrole ring to favor oxygen reduction. Electrochemical and spectroscopic measurements show that the diprotonated form of this molecule acts as a catalyst for the reduction of oxygen by a weak electron donor in the organic phase, namely ferrocene, provided that the counteranion is properly chosen.

\section{Experimental Section}

2.1. Chemicals. All solvents and chemicals were used as received without further purification. Lithium tetrakis(pentafluorophenyl)borate diethyl etherate (LiTB), ferrocene $(\mathrm{Fc}, \geq 98 \%)$ and $\mathrm{HClO}_{4}(70 \%)$ were provided by Sigma-Aldrich. Trifluoroacetic acid (TFA) was purchased from Acros. Hydrochloric acid $(\mathrm{HCl})$, anhydrous lithium chloride ( $\mathrm{LiCl}, \geq 99 \%)$, 1,2-dichloroethane (DCE, $\geq 99.8 \%$ ), sodium iodide (NaI, $>99.5 \%$ ), tetraethylammonium chloride (TEACl, $\geq 98 \%$ ), and bis(triphenylphosphoranylidene)ammonium chloride (BACl, $\geq 98 \%$ ) were obtained from Fluka. Bis(triphenylphosphoranylidene)ammonium tetrakis(pentafluorophenyl)borate (BATB) was prepared by metathesis of 1:1 mixtures of $\mathrm{BACl}$ and LiTB in a methanol/water mixture $(V: V=2: 1)$, followed

(10) Cunnane, V. J.; Geblewicz, G.; Schifferin, D. J. Electrochim. Acta 1995, 40, 3005-3014.

(11) Liljeroth, P.; Quinn, B. M.; Kontturi, K. Langmuir 2003, 19, 51215127.

(12) Ohde, H.; Maeda, K.; Yoshida, Y.; Kihara, S. J. Electroanal. Chem. 2000, 483, 108-116.

(13) Suzuki, M.; Matsui, M.; Kihara, S. J. Electroanal. Chem. 1997, 438, $147-151$.

(14) Hatay, I.; Su, B.; Li, F.; Mendez, M. A.; Khoury, T.; Gros, C. P.; Barbe, J.-M.; Ersoz, M.; Samec, Z.; Girault, H. H. J. Am. Chem. Soc. 2009, 131, 13453-13459.

(15) Partovi-Nia, R.; Su, B.; Li, F.; Gros, C. P.; Barbe, J.-M.; Samec, Z.; Girault, H. H. Chem.-Eur. J. 2009, 15, 2335-2340.

(16) Su, B.; Nia, R. P.; Li, F.; Hojeij, M.; Prudent, M.; Corminboeuf, C.; Samec, Z.; Girault, H. H. Angew. Chem., Int. Ed. 2008, 47, 46754678.

(17) Trojanek, A.; Langmaier, J.; Samec, Z. Electrochem. Commun. 2006, $8,475-481$.

(18) Trojanek, A.; Langmaier, J.; Su, B.; Girault, H. H.; Samec, Z. Electrochem. Commun. 2009, 11, 1940-1943.

(19) Trojanek, A.; Marecek, V.; Janchenova, H.; Samec, Z. Electrochem. Commun. 2007, 9, 2185-2190.

(20) Trojanek, A.; Langmaier, J.; Samec, Z. Electrochem. Commun. 2006, $8,475-481$.

(21) Su, B.; Hatay, I.; Li, F.; Partovi-Nia, R.; Mendez, M. A.; Samec, Z.; Ersoz, M.; Girault, H. H. J. Electroanal. Chem. 2010, 639, 102-108. by recrystallization from acetone. ${ }^{22}$ All the aqueous solutions were prepared with ultra pure water $(18.2 \mathrm{M} \Omega \mathrm{cm})$. The $\mathrm{pH}$ of the aqueous solutions was adjusted by addition of $\mathrm{HCl}$. All the chemicals used for synthesis of 5-( $p$-aminophenyl)-10,15,20tris(pentafluorophenyl)porphyrin $\left(\mathrm{H}_{2} \mathrm{FAP}\right)$ were bought from either Acros or Aldrich. HTB was prepared by shaking $x \mathrm{mM} \mathrm{LiTB}$ and $10 \mathrm{mM} \mathrm{HCl}$ in the water phase with pure DCE for $1 \mathrm{~h}$. The concentration of HTB extracted to DCE was approximately $x \mathrm{mM}$, as determined by the $\mathrm{pH}$ change of the water phase before and after shaking.

2.2. Spectrophotometric Titration. $\mathrm{H}_{2} \mathrm{FAP}$ in DCE was titrated in a small flask by addition of concentrated trifluoroacetic acid (TFA) in DCE (1 $\mathrm{mM}$ to $1 \mathrm{M})$. The total volume was adjusted to $1 \mathrm{~mL}$ with DCE to give a concentration of $\mathrm{H}_{2} \mathrm{FAP}$ at $20 \mu \mathrm{M}$. The flask was capped and shaken for a sufficient reaction, and then the UV-visible spectrum was measured on an Ocean Optical CHEM2000 spectrophotometer using a quartz cuvette (path length $10 \mathrm{~mm}$ ).

2.3. Electrochemical Measurements. Electrochemical measurements at the water/DCE interface were performed in a four-electrode configuration with a commercial potentiostat (PGSTAT 30, EcoChemie, Netherlands) or on a custom-built four-electrode system connected to a DS335 synthesized function generator (Stanford Research System). A three-compartment cell featuring a crosssection of $1.53 \mathrm{~cm}^{2}$ and two side Luggin capillaries was employed. The external potential was applied by means of the two reference electrodes, silver/silver chloride $(\mathrm{Ag} / \mathrm{AgCl})$ wires, placed in two Luggin capillaries. The composition of the electrochemical cell is displayed in Scheme 3. The Galvani potential difference $\left(\Delta_{\mathrm{o}}^{\mathrm{w}} \phi\right)$ was estimated by taking the formal ion transfer potential of tetraethylammonium cation $\left(\mathrm{TEA}^{+}\right)$as $0.019 \mathrm{~V}^{23}$ All the electrochemical measurements were performed at ambient temperature $\left(23 \pm 2{ }^{\circ} \mathrm{C}\right)$ with air-saturated solutions.

2.4. Two-Phase Reactions. The two-phase reactions were performed in a small flask under stirring conditions. DCE solution $\left(2 \mathrm{~mL}\right.$ ) containing either $5 \mathrm{mM} \mathrm{Fc}$ or $5 \mathrm{mM} \mathrm{Fc}$ and $30 \mu \mathrm{M} \mathrm{H}_{2} \mathrm{FAP}$ was added to the flask, followed by the addition of $2 \mathrm{~mL}$ of aqueous solution containing $10 \mathrm{mM} \mathrm{HCl}$ on the top. The aqueous and organic salts of common ion, LiTB and BATB, were added at the same concentration of $5 \mathrm{mM}$. The two phases were stirred for $30 \mathrm{~min}$ then left for phase separation, and the aqueous and organic solutions were isolated from each other. The organic phase was directly subjected to the UV-visible spectroscopic measurement, while the aqueous phase was treated with excess $\mathrm{NaI}$ prior to the spectroscopic measurement.

2.5. Spectrophometric Study of Oxygen Reduction by Ferrocene Catalyzed by $\mathbf{H}_{2}$ FAP. The course of the oxidation reaction of $\mathrm{Fc}$ by $\mathrm{O}_{2}$ was monitored by visible absorption spectrophotometry at the maximum of the $\mathrm{Fc}^{+}$band $(\lambda=620 \mathrm{~nm})$ on a Cary 50 (Varian) instrument. The temperature was maintained constant at 298.2(2) K by water circulation through the doublewalled cell holder connected to a RE106 (Lauda) bath. Stock solutions of all reagents were prepared in DCE $\left(\left[\mathrm{H}_{2} \mathrm{FAP}\right]=500\right.$ $\mu \mathrm{M},[\mathrm{Fc}]=24.7 \mathrm{mM},[\mathrm{HTB}]=10.6 \mathrm{mM})$. In a typical experiment, $0.2 \mathrm{~mL}$ of $\mathrm{H}_{2} \mathrm{FAP}$ and $0.4 \mathrm{~mL}$ of HTB solutions were diluted with $1.0 \mathrm{~mL}$ of pure DCE in a quartz cell (Hellma) of $1 \mathrm{~cm}$ path length. After setting the optical density value of the mixture to zero, an aliquot $(0.4 \mathrm{~mL})$ of Fc solution was injected. Reactants were rapidly mixed by shaking vigorously the cuvette, after which the absorbance changes as a function of time were recorded. Since TFA is a much weaker proton donor in DCE than HTB, $15 \mu \mathrm{L}$ of commercial acid $(13.3 \mathrm{M})$ diluted in $1.385 \mathrm{~mL}$ of DCE were introduced in the cell before adding $0.4 \mathrm{~mL}$ of the $\mathrm{Fc}$ solution. For the control experiment carried out in the absence of porphyrin, an equivalent amount of solvent was added in order to keep the HTB and Fc concentrations

(22) Su, B.; Abid, J.-P.; Fermin, D. J.; Girault, H. H.; Hoffmannova, H.; Krtil, P.; Samec, Z. J. Am. Chem. Soc. 2004, 126, 915-919.

(23) Wandlowski, T.; Marecek, V.; Samec, Z. Electrochim. Acta 1990, 35, $1173-1175$ 
Scheme 1. Synthetic Pathway Leading to $\mathrm{H}_{2} \mathrm{FAP}$

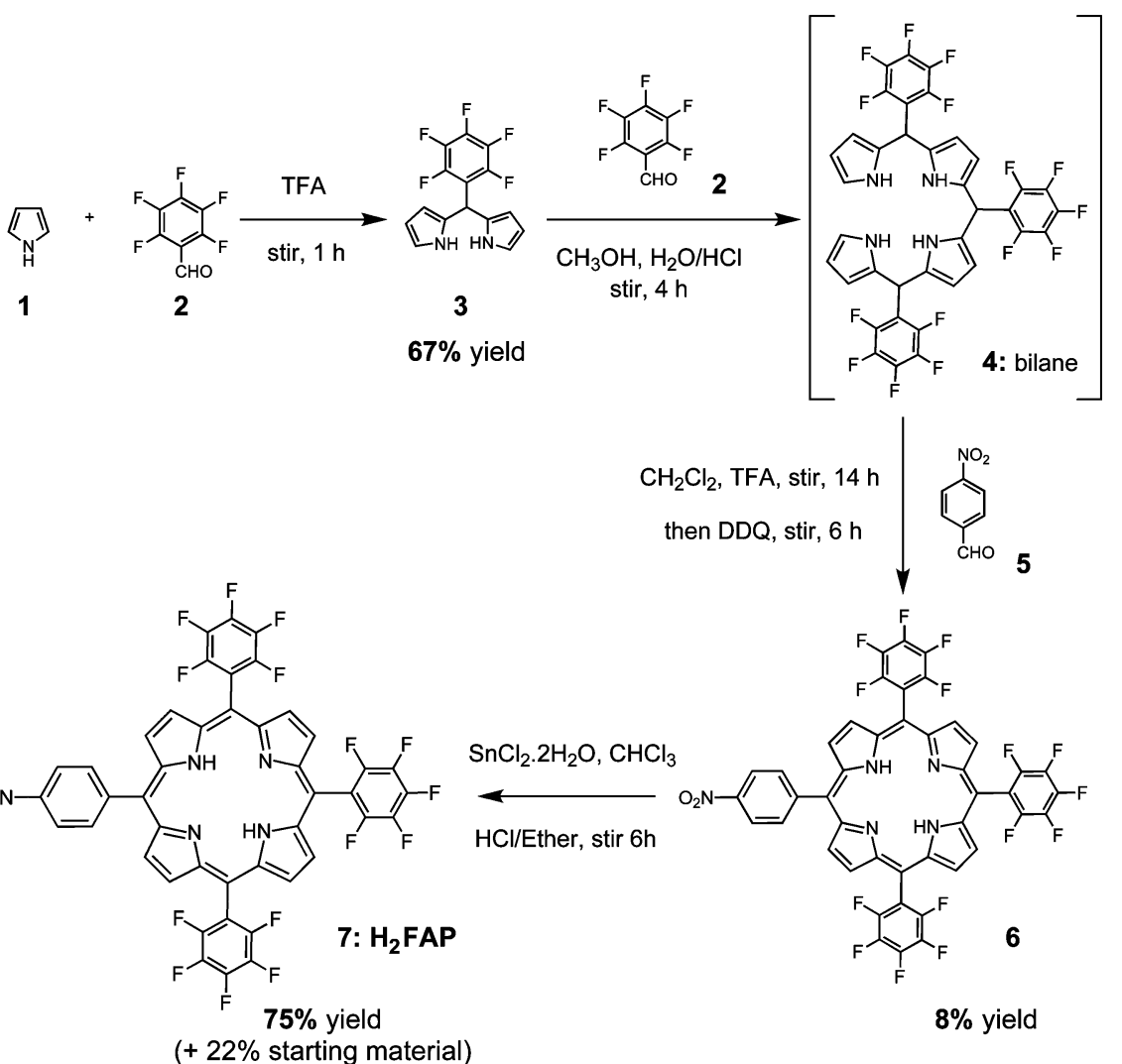

identical to those used in the catalyzed reaction. Final concentrations were $\left[\mathrm{H}_{2} \mathrm{FAP}\right]=50 \mu \mathrm{M},[\mathrm{Fc}]=4.94 \mathrm{mM},[\mathrm{HTB}]=2.12 \mathrm{mM}$ or $[\mathrm{TFA}]=0.10 \mathrm{M}$. The oxygen concentration was limited by the solubility $(1.39 \mathrm{mM})$ and rapid diffusion of $\mathrm{O}_{2}$ in DCE. Airsaturated solutions afforded the same kinetic traces whether or not the headspace of the cuvette was maintained under a slight overpressure of pure dioxygen.

2.6. Computation. All the geometries were optimized at the M05-2X ${ }^{24} / \mathrm{cc}-\mathrm{pVDZ}^{25}$ level using Gaussian09. ${ }^{26}$ Zero-point corrected relative energies are computed at the same level for the protonated forms of the fluorinated free base porphyrin. Only the lowest energy form of $\mathrm{H}_{3} \mathrm{FAP}^{+}$protonated in the tetrapyrrole ring was considered. The binding energies for the complexes $\left(\left[\mathrm{H}_{3} \mathrm{FAP}{ }^{+}\right.\right.$ $\left.\cdots \mathrm{O}_{2}\right]$ and $\left[\mathrm{H}_{4} \mathrm{FAP}^{2+} \cdots \mathrm{O}_{2}\right]$ ) correspond to the energy difference between the complexes and its separate adducts (i.e., triplet oxygen and singlet $\left.\mathrm{H}_{3} \mathrm{FAP}^{+} / \mathrm{H}_{4} \mathrm{FAP}^{2+}\right)$. Those binding energies were computed using RI-LMP2 $27,28 / c c-p V D Z$ single-point energies in a developmental version of Q-Chem. ${ }^{29}$ No symmetry was exploited and the convergence criterion for the reference wave function was set to $10^{-6}$, core electrons were kept frozen and the standard auxiliary basis set was used for the resolution-of-identity (RI). For all other settings the default values were adopted. Open-shell structures (i.e. the complexes and the oxygen molecule) were treated in the unrestricted formalism. LMP2 in Q-Chem refers to the

(24) Zhao, Y.; Schultz, N. E.; Truhlar, D. G. J. Chem. Theory Comput. 2006, 2, 364-382.

(25) Dunning, T. H., Jr. J. Chem. Phys. 1989, 90, 1007-1023.

(26) Frisch, M. J.; et al. Gaussian 09, Revision A.02; Gaussian Inc.: Wallingford CT, 2009.

(27) Lee, M. S.; Maslen, P. E.; Head-Gordon, M. J. J. Chem. Phys. 2000, $112,3592-3601$

(28) DiStasio, R. A.; Jung, Y.; Head-Gordon, M. J. J. Chem. Theory Comput. 2005, 1, 862-876.

(29) Shao, Y.; et al. Phys. Chem. Chem. Phys. 2006, 8, 3172-3191. triatomics in molecules (TRIM) ${ }^{30}$ approach, which reduces the basis set superposition error (BSSE) and, more importantly, the computational cost.

\section{Results and Discussion}

3.1. Synthesis of $\mathbf{H}_{2} \mathbf{F A P}$. The stepwise synthesis of the 5-( $p$ aminophenyl)-10,15,20-tris(pentafluorophenyl) porphyrin 7 $\left(\mathrm{H}_{2}\right.$ FAP) was achieved as described in Scheme 1 and in the Supporting Information. The preparation of the 5-(pentafluorophenyl)dipyrromethane 3 was performed in $67 \%$ yield starting from pyrrole 1 and pentafluorobenzaldehyde $\mathbf{2}$ (Scheme 1); the dipyrromethane was used in order to prepare the bilane intermediate 4 which was then condensed with 4-nitro-benzaldehyde $\mathbf{5}$ in a stirring dichloromethane/trifluoroacetic acid medium to give the nitrophenyl-tris(pentafluorophenyl) porphyrin $\mathbf{6}$ in $8 \%$ yield. Tin(II) chloride mediated reduction of $\mathbf{6}$ gave the expected free-base amino-porphyrin $\mathrm{H}_{2}$ FAP 7 in $75 \%$ yield. $\mathrm{H}_{2}$ FAP 7 was fully characterized by HRMS, ${ }^{1} \mathrm{H} \mathrm{NMR}$, and UV-vis spectroscopy (see Supporting Information for details).

3.2. Spectrophotometric Titration of $\mathbf{H}_{2} \mathbf{F A P}$. When considering the molecular structure of $\mathrm{H}_{2} \mathrm{FAP}$, both the two imino nitrogen atoms in the tetrapyrrole ring and the peripheral amine can be protonated. To verify that the amino group, used to confer some amphiphilic character to the molecule, does not interfere with the protonation of the ring, a spectrophotometric titration of $\mathrm{H}_{2} \mathrm{FAP}$ with an organic soluble acid, TFA, was performed in DCE. Figure 1 illustrates the absorption spectra of successive acid titration products of $\mathrm{H}_{2} \mathrm{FAP}$, which show that protonation occurs in two well-separated stages with good sets of isosbestic

(30) Weigend, F.; Kohn, A.; Hattig, C. J. Chem. Phys. 2002, 116, 31753183. 

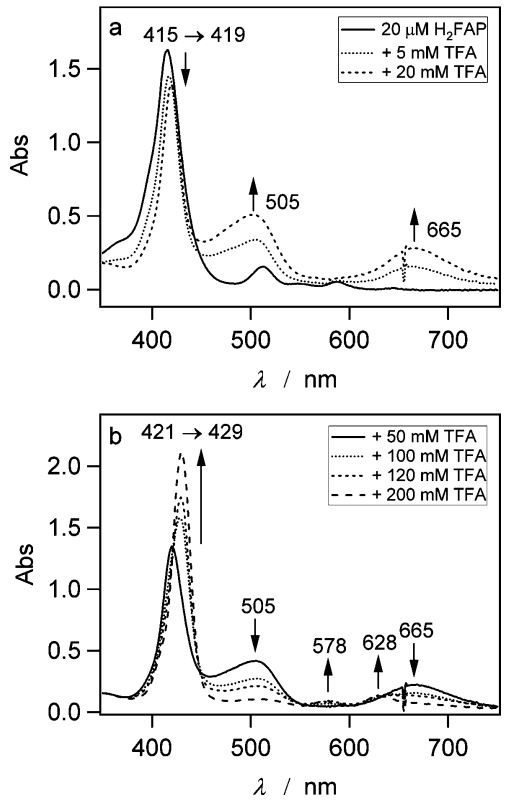

Figure 1. Spectrophotometric titration of $20 \mu \mathrm{M} \mathrm{H}_{2} \mathrm{FAP}$ in DCE by TFA: (a) at TFA concentrations lower than $50 \mathrm{mM}$; (b) at TFA concentrations higher than $50 \mathrm{mM}$.

points. At the first stage of protonation (Figure 1a), when the TFA concentration is lower than $50 \mathrm{mM}$, adding TFA to a $\mathrm{H}_{2} \mathrm{FAP}$ solution led to a slight decrease and red-shift (from 415 to $419 \mathrm{~nm}$ ) of the Soret band, as well as the disappearance of the four Q bands $\left(\lambda_{\max }=513,548,587\right.$, and $\left.644 \mathrm{~nm}\right)$ and the appearance of two new but broad Q bands $\left(\lambda_{\max }=505\right.$ and $665 \mathrm{~nm}$ ) that increase with increasing TFA concentration. The second stage at much higher TFA concentrations (Figure 1b) resulted in a sharp Soret band $\left(\lambda_{\max }=429 \mathrm{~nm}\right)$, the intensity of which increases with increasing concentrations of acid. Moreover, the two Q bands at 505 and $665 \mathrm{~nm}$ are damped and finally replaced by two new bands with $\lambda_{\max }=578$ and $628 \mathrm{~nm}$. All these experimental results are indeed similar to those observed previously for a free base tetraphenylporphyrin bearing one aminophenyl group at one meso-position. ${ }^{31}$ The protonation sites at the first stage can therefore be assigned to both imino nitrogen atoms in the tetrapyrrole ring leading to the formation of $\mathrm{H}_{4} \mathrm{FAP}^{2+}$, while the second stage can be assigned to the protonation of the single peripheral amine. These conclusions are also supported by density functional theory computations as illustrated in Scheme 2. The M05-2X/cc-pVDZ relative energies of the protonated forms of $\mathrm{H}_{2} \mathrm{FAP}$ indeed demonstrate that the protonation first occurs on the imino nitrogen atoms of the porphyrin ring. The protonation of the peripheral amine is disfavored by $\sim 30 \mathrm{kcal} \mathrm{mol}^{-1}$. The binding energy of a second proton on the ring is found to be rather easy:

$$
\begin{aligned}
& \mathrm{H}_{2} \mathrm{FAP}+\mathrm{H}_{3} \mathrm{O}^{+} \rightarrow \mathrm{H}_{3} \mathrm{FAP}^{+}+\mathrm{H}_{2} \mathrm{O}-68.9 \mathrm{kcal} \cdot \mathrm{mol}^{-1} \\
& \mathrm{H}_{3} \mathrm{FAP}^{+}+\mathrm{H}_{3} \mathrm{O}^{+} \rightarrow \mathrm{H}_{4} \mathrm{FAP}^{2+}+\mathrm{H}_{2} \mathrm{O}-5.1 \mathrm{kcal} \cdot \mathrm{mol}^{-1}
\end{aligned}
$$

3.3. Ion-Transfer Voltammetry of $\mathrm{H}_{2} \mathrm{FAP}$ and Determination of $\mathbf{p} \boldsymbol{K}_{\mathbf{a}}{ }^{\mathbf{D C E}}$. Electrochemical measurements at the water/DCE interface were carried out so as to characterize the acid-base properties of the fluorinated porphyrin. Figure 2 a shows the cyclic voltammograms of the water/DCE interface obtained in the absence (dotted line) and presence (full line) of $100 \mu \mathrm{M}$ $\mathrm{H}_{2}$ FAP. As can be seen, the presence of $\mathrm{H}_{2}$ FAP in DCE resulted in a single voltammetric wave at positive potentials. The absence of a clear and well-defined wave for the second protonation of the free-base could be due either to its extreme hydrophobicity, so that it cannot be observed within the potential window, or to the close proximity between the two $\mathrm{p} K_{\mathrm{a}}$ values. Considering that the monoprotonated species cannot be observed by spectrophotometric titration, it is very likely that two successive protonations occur in a narrow potential range, which can be equivalent to two successive $E E$ reactions in the classical cyclic voltammetry of electron transfer reactions $(E)$ on solid electrodes. If the second protonation would have been easier than the first one, the voltammetric signal should correspond to the simultaneous transfer of two protons, and the peak-to-peak separation would be $29 \mathrm{mV}$. If the two protonations have exactly

Scheme 2. Structures and Relative Energies of $\mathrm{H}_{3} \mathrm{FAP}^{+}$Protonated Either on the Ring (left) or on the Amino Group (right); (Top) Top View; (Bottom) Side View
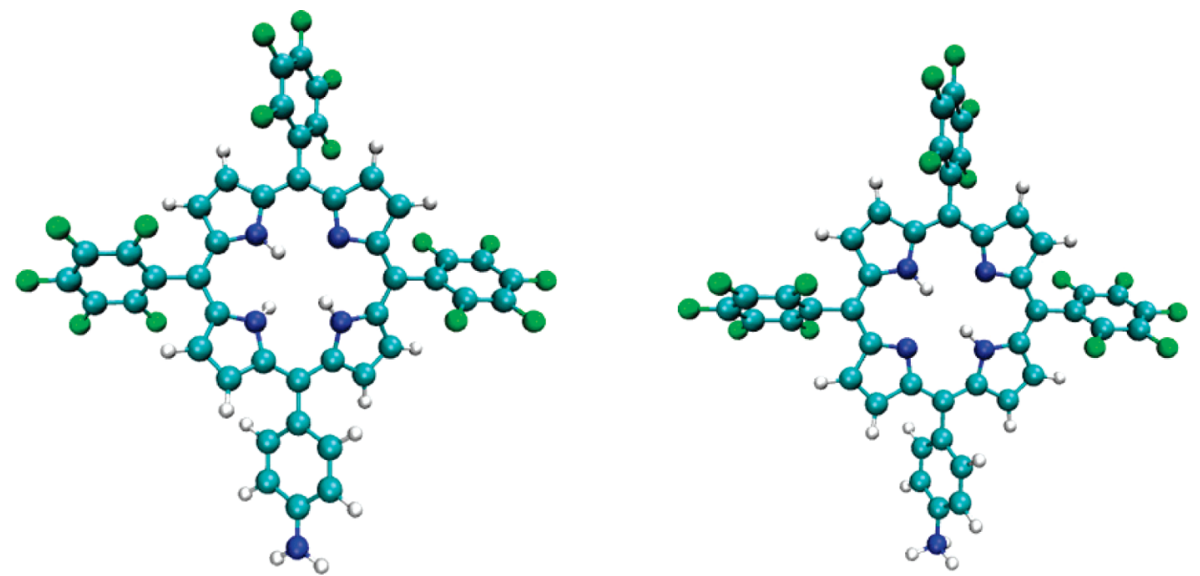

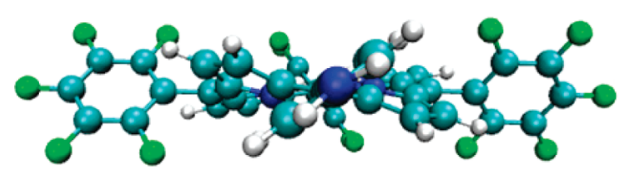

$0 \mathrm{kcal} \mathrm{mol}^{-1}$

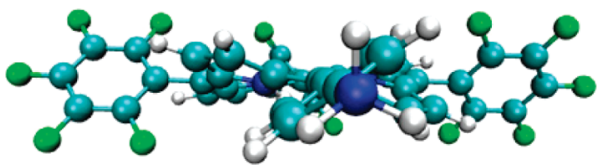

$30.5 \mathrm{kcal} \mathrm{mol}^{-1}$ 

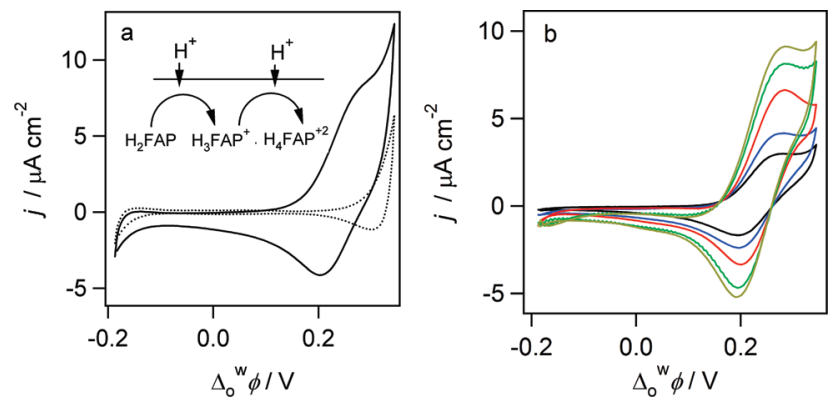

Figure 2. (a) Cyclic voltammograms in the absence (dotted line) and presence (full line) of $\mathrm{H}_{2} \mathrm{FAP}$ in DCE at a scan rate of $50 \mathrm{mV} \mathrm{s}^{-1}$ (Scheme 3: $x=100 \mu \mathrm{M}, y=0, z=100 \mathrm{mM}$ ). (b) Background subtracted voltammograms for $100 \mu \mathrm{M} \mathrm{H}_{2} \mathrm{FAP}$ facilitated proton transfer reactions at various scan rates (Scheme 3: $x=100 \mu \mathrm{M}, y=0, z=100 \mathrm{mM}$ ): 10, 20, 50,80 , and $100 \mathrm{mV} \mathrm{s}^{-1}$ from inner to outer.

Scheme 3. Composition of the Electrochemical Cell

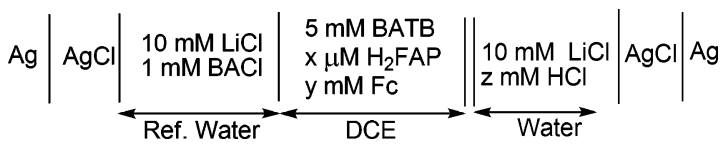

the same $\mathrm{p} K_{\mathrm{a}}$ values, only one wave would be observed but with a peak-to-peak separation of $41 \mathrm{mV}$ (see Figure S1, Supporting Information), as calculated by Digisim software. Here, the peak-to-peak separation after background subtraction and extrapolation to zero scan rate was measured to be $60 \mathrm{mV}$ (see Figure 2b), what is classically obtained for a single ion transfer. However, the same peak-to-peak separation can be obtained for two successive reactions for which the half-wave potentials are separated by $38 \mathrm{mV}$, as calculated by Digisim software. In other words, these voltammetric data suggest a double assisted proton transfer reaction for which the two $\mathrm{p} K_{\mathrm{a}}$ values are separated by at least $0.65 \mathrm{pH}$ unit. Digisim fits of experimental data gives a diffusion coefficient value of $8 \times$ $10^{-7} \mathrm{~cm}^{2} \cdot \mathrm{s}^{-1}$ compared to a value of $3 \times 10^{-6} \mathrm{~cm}^{2} \cdot \mathrm{s}^{-1}$ for $\mathrm{H}_{2}$ TPP measured in the same conditions. (see Figures S2 and S3, respectively (Supporting Information)).

Furthermore, the magnitude of this current wave does not change with the acidity of the aqueous phase, whereas the wave continuously moves to positive potentials with the half-wave potential shifting by approximately $60 \mathrm{mV} / \mathrm{pH}$ unit, as displayed in $a$ and $b$ of Figure 3. These data indicate that the voltammetric wave corresponds to the assisted transfer of two successive protons from water to DCE by $\mathrm{H}_{2} \mathrm{FAP}$, i.e. the diprotonation of $\mathrm{H}_{2} \mathrm{FAP}$ at the interface.

The interfacial reaction is limited by the linear diffusion of $\mathrm{H}_{2} \mathrm{FAP}$ in the organic phase toward the interface. Moreover, ion-transfer voltammetry allows the estimation of dissociation constant if one takes into account the following protonation reactions:

$$
\begin{aligned}
& \mathrm{H}_{4} \mathrm{FAP}_{(\mathrm{DCE})}^{2+} \rightleftarrows \mathrm{H}_{3} \mathrm{FAP}_{(\mathrm{DCE})}^{+}+\mathrm{H}_{(\mathrm{DCE})}^{+} K_{\mathrm{a} 1} \\
& \mathrm{H}_{3} \mathrm{FAP}_{(\mathrm{DCE})}^{+} \rightleftarrows \mathrm{H}_{2} \mathrm{FAP}_{(\mathrm{DCE})}+\mathrm{H}_{(\mathrm{DCE})}^{+} K_{\mathrm{a} 2}
\end{aligned}
$$

Thus, the half-wave potential of the first protonation $\Delta_{\mathrm{o}}^{\mathrm{w}} \phi_{\mathrm{H}_{3} \mathrm{FAP}^{+}}^{1 / 2}$ depends on the $\mathrm{pH}$ according to the following equation:

(31) Ojadi, E. C. A.; Linschitz, H.; Gouterman, M.; Walter, R. I.; Lindsey, J. S.; Wagner, R. W.; Droupadi, P. R.; Wang, W. J. Phys. Chem. 1993, 97, 13192-13197.
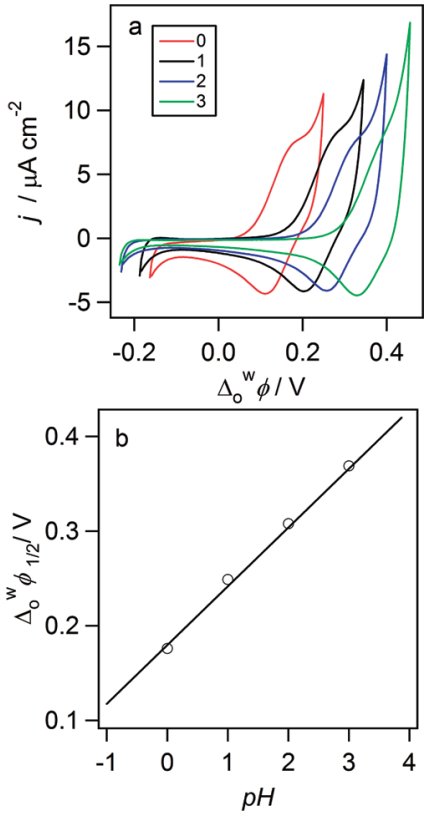

Figure 3. (a) Cyclic voltammograms in the presence of $\mathrm{H}_{2} \mathrm{FAP}$ in DCE at different $\mathrm{pH}$ values (Scheme 3: $x=100 \mu \mathrm{M}, y=0$ ), scan rate $50 \mathrm{mV} \mathrm{s}^{-1}$. (b) $\mathrm{pH}$ dependence of the half-wave potentials.

$$
\begin{aligned}
\Delta_{\mathrm{o}}^{\mathrm{w}} \phi_{\mathrm{H}_{3} \mathrm{FAP}^{+}}^{1 / 2}=\Delta_{\mathrm{o}}^{\mathrm{w}} \phi_{\mathrm{H}^{+}}^{0}+\frac{R T}{2 F} \ln \left(\frac{D_{\mathrm{H}_{2} \mathrm{FAP}}}{D_{\mathrm{H}_{3} \mathrm{FAP}^{+}}}\right)+ & \frac{R T}{F} \ln K_{\mathrm{a} 2}+ \\
& \frac{2.303 R T}{F} \mathrm{pH}^{\mathrm{w}}
\end{aligned}
$$

with the second acidity constant in the organic phase defined as:

$$
K_{\mathrm{a} 2}=\frac{a_{\mathrm{H}_{2} \mathrm{FAP}} a_{\mathrm{H}^{+}}}{a_{\mathrm{H}_{3} \mathrm{FAP}}}
$$

where $\Delta_{\mathrm{o}}^{\mathrm{w}} \phi_{0} \mathrm{H}^{+}$is the standard transfer potential of $\mathrm{H}^{+} . D_{\mathrm{H}_{2} \mathrm{FAP}}$ and $D_{\mathrm{H}_{3} \mathrm{FAP}^{+}}$represent the diffusion coefficients of the proton acceptor ligand and its protonated form, and $D_{\mathrm{H}_{2} \mathrm{FAP}} \approx D_{\mathrm{H}_{3} \mathrm{FAP}^{+}}$ can be assumed for simplicity. $\mathrm{pH}^{\mathrm{w}}$ is the aqueous $\mathrm{pH}$ and $K_{\mathrm{a} 2}$ is the dissociation constant of $\mathrm{H}_{3} \mathrm{FAP}^{+}$in DCE. $a_{\mathrm{H}_{2} \mathrm{FAP}}, a_{\mathrm{H}^{+}}$, and $a_{\mathrm{H}_{3} \mathrm{FAP}^{+}}$are the activities of $\mathrm{H}_{2} \mathrm{FAP}$, proton, and $\mathrm{H}_{3} \mathrm{FAP}^{+}$in DCE, respectively. As shown in Figure $3 b$, the relationship between $\Delta_{\mathrm{o}}^{\mathrm{w}} \phi_{\mathrm{H}_{3} \mathrm{FAP}^{+}}^{1 / 2}$ taken as a first approximation as the midpeak potential and the $\mathrm{pH}^{\mathrm{w}}$ is found to be linear with a slope of $63.8 \mathrm{mV}$, and $K_{\mathrm{a} 2}$ value for $\mathrm{H}_{3} \mathrm{FAP}^{+}$was determined to be equal to $5.5 \times$ $10^{-7}$. Since the two half-wave potential values are separated by at least $0.65 \mathrm{pH}$ unit, the first $K_{\mathrm{a} 1}$ value can be estimated to be at least $2.5 \times 10^{-6}$.

As reported previously and shown in Figure S3 (Supporting Information), in the case of 5,10,15,20-tetraphenylporphyrin $\left(\mathrm{H}_{2} \mathrm{TPP}\right)$ it was possible to observe the two successive protonations of the two imino nitrogen atoms of the porphyrin ring with dissociation constants of $1.6 \times 10^{-10}$ and $1.0 \times 10^{-6}$ for $\mathrm{H}_{3} \mathrm{TPP}^{+}$and $\mathrm{H}_{4} \mathrm{TPP}^{2+}$ by ion-transfer voltammetry. ${ }^{32}$ Compared to the structure of $\mathrm{H}_{2} \mathrm{TPP}, \mathrm{H}_{2} \mathrm{FAP}$ has three pentafluorinated phenyl groups that exhibit a strong electron-withdrawing effect, leading to the electron deficiency in the tetrapyrrole ring and thus to a weaker basicity of the imino nitrogen atoms. It means

(32) Su, B.; Li, F.; Partovi-Nia, R.; Gros, C. P.; Barbe, J.-M.; Samec, Z.; Girault, H. H. Chem. Commun. 2008, 5037-5038. 

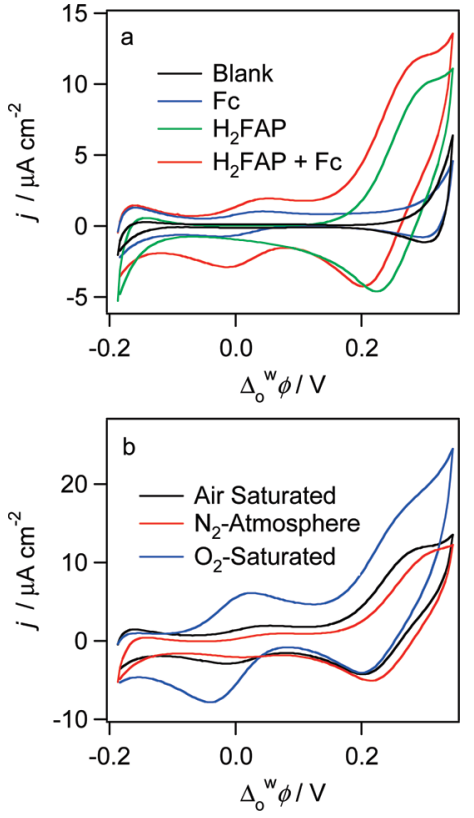

Figure 4. Cyclic voltammograms of $\mathrm{Fc}$ obtained at a water/DCE interface with the cell illustrated in Scheme 3. (a) $x=0$ and $y=0$ (black), $x=100$ $\mu \mathrm{M}$ and $y=0$ (green), $x=0$ and $y=5 \mathrm{mM}$ (blue) and $x=100 \mu \mathrm{M}$ and $y=5 \mathrm{mM}$ (red). (b). $x=100 \mu \mathrm{M}$ and $y=5 \mathrm{mM}$ under air-saturated (black), anaerobic (red) and oxygen-saturated (blue) conditions. The $\mathrm{pH}$ was kept constant, $z=100 \mathrm{mM}$. The curves show the first scans.

that $\mathrm{H}_{2} \mathrm{FAP}$ is more difficult to protonate than $\mathrm{H}_{2} \mathrm{TPP}$. Therefore, what is observed in the ion-transfer voltammetry corresponds to the successive protonations of the imino nitrogen atoms to form the diacid $\mathrm{H}_{4} \mathrm{FAP}^{2+}$. It should be mentioned that no protonation of the amino group was observed during this experiment.

3.4. $\mathrm{H}_{4} \mathrm{FAP}^{2+}$ Catalysis of Oxygen Reduction by Fc. Fc does not react with $\mathrm{O}_{2}$ in the absence of catalyst at least on the time scale of a day. Figure 4a compares the cyclic voltammograms in the presence of only Fc (blue line), in the presence of only $\mathrm{H}_{2} \mathrm{FAP}$ (green line) and in the presence of both (red line) under experimental conditions given in Scheme 3. The current wave with a half-wave potential close to $0 \mathrm{~V}$ when adding only $\mathrm{Fc}$ in DCE corresponds to the transfer of ferrocenium $\left(\mathrm{Fc}^{+}\right)$across the water/DCE interface. $\mathrm{Fc}^{+}$stems from a slow oxidation of $\mathrm{Fc}$ in the stock solution, and is used here as an internal potential reference. In the presence of both $\mathrm{Fc}$ and $\mathrm{H}_{2} \mathrm{FAP}$ in DCE, the current wave originating from the double assisted proton transfer by $\mathrm{H}_{2}$ FAP seems not to be affected, being only shifted by the back transfer of $\mathrm{Fc}^{+}$from water to DCE. However, the current wave corresponding to the transfer of $\mathrm{Fc}^{+}$from DCE to water is significantly increased indicating that $\mathrm{Fc}^{+}$is generated upon polarizing the interface to positive values. Moreover, Figure $4 \mathrm{~b}$ shows that the generation of $\mathrm{Fc}^{+}$does not occur under anaerobic conditions but increases under oxygen-saturated conditions. These data suggest that the transfer of protons facilitated by $\mathrm{H}_{2} \mathrm{FAP}$ induces an oxygen reduction by $\mathrm{Fc}$, thereby forming $\mathrm{Fc}^{+}$. Although $\mathrm{H}_{2} \mathrm{FAP}$ is a free base porphyrin, it exhibits a catalytic behavior similar to that of cobalt tetraphenylporphyrin (CoTPP) toward oxygen reduction by Fc. ${ }^{15}$

This process is equivalent to a catalytic $E E C$ reaction scheme in the classical electrode/solution electrochemistry, involving two successive electron transfer reactions $(E E)$ at the electrode/ solution interface followed by a chemical reaction $(C)$ in the solution regenerating the starting reactant. Here, the double-
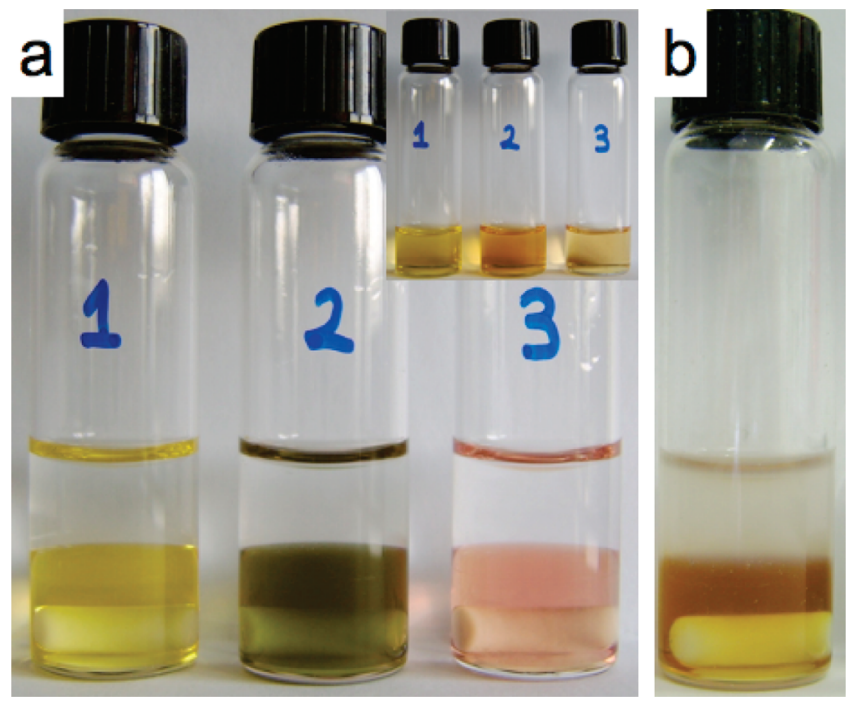

Figure 5. (a) Two-phase reaction controlled by $\mathrm{TB}^{-}$partition after $30 \mathrm{~min}$ shaking: the top aqueous phase contains $5 \mathrm{mM} \mathrm{LiTB}+10 \mathrm{mM} \mathrm{HCl}$ in all three flasks; the bottom DCE phase contains $5 \mathrm{mM} \mathrm{Fc}, 5 \mathrm{mM} \mathrm{Fc}+30 \mu \mathrm{M}$ $\mathrm{H}_{2} \mathrm{FAP}$ and $30 \mu \mathrm{M} \mathrm{H}_{2} \mathrm{FAP}$ in the flask 1,2 , and 3, respectively; the inset shows the flasks before adding water phase. (b) A two-phase reaction under anaerobic conditions, the concentrations are the same as those for flask 2 in Figure 5a.

assisted proton transfer step represents a faradaic process with an ionic flux across the interface, thus being equivalent to the $E E$ step. The oxygen reduction reaction involving $\mathrm{H}_{4} \mathrm{FAP}^{2+}$, $\mathrm{Fc}$, and $\mathrm{O}_{2}$ is the following $C$ step to produce $\mathrm{H}_{2} \mathrm{O}_{2}$ and regenerate the catalyst $\mathrm{H}_{2} \mathrm{FAP}$. Unfortunately, the chemical step is too slow with respect to the ion transfer reaction to affect the voltammetric signal for the double protonation of $\mathrm{H}_{2}$ FAP. In this case, voltammetry can only be used to observe the formation of ferrocenium in the organic phase after the formation of $\mathrm{H}_{4} \mathrm{FAP}^{2+}$ in aerobic conditions.

To further study this catalytic process, we have used biphasic reaction conditions to investigate the role of $\mathrm{H}_{4} \mathrm{FAP}^{2+}$ and to identify the reaction products. A chemical way to drive aqueous protons to the organic phase is to add a very lipophilic anion to the aqueous phase. Here, we have used tetrakis(pentafluorophenyl)borate $\left(\mathrm{TB}^{-}\right)$to form, by extraction, the organic acid HTB. As illustrated in Figure 5a, $10 \mathrm{mM} \mathrm{HCl}$ was present in the top aqueous phase in all three flasks, while the DCE phase contained $5 \mathrm{mM} \mathrm{Fc}$ in flask $1,30 \mu \mathrm{M} \mathrm{H}_{2} \mathrm{FAP}$ in flask 3 , and both reagents in flask 2. The color of the DCE phases is shown in the inset of Figure $5 \mathrm{a}$ before addition of the aqueous phase. After adding the water phase and stirring for $30 \mathrm{~min}$, the color of the DCE phase in flask 1 did not change, indicating that no reaction took place. When only $\mathrm{H}_{2} \mathrm{FAP}$ is present in the DCE phase (flask 3 ), the color change of the organic layer from orange to pink is indicative of the protonation of $\mathrm{H}_{2} \mathrm{FAP}$. In the presence of both $\mathrm{Fc}$ and $\mathrm{H}_{2} \mathrm{FAP}$ (flask 2), the color results from a mixture of green $\mathrm{Fc}^{+}$and pink $\mathrm{H}_{2} \mathrm{FAP}$. Moreover, the experiment performed in the absence of oxygen showed that the DCE solution containing $\mathrm{Fc}$ and $\mathrm{H}_{2} \mathrm{FAP}$ did not change its color even after stirring for $3 \mathrm{~h}$ as shown in Figure $5 \mathrm{~b}$.

After separation of both phases, the UV-visible absorption spectra of DCE layers were recorded, whereas the aqueous phases were titrated with $\mathrm{NaI}$. When both $\mathrm{Fc}$ and $\mathrm{H}_{2} \mathrm{FAP}$ were present in the DCE phase, the formation of $\mathrm{Fc}^{+}$could be clearly observed, as shown by the characteristic absorption band with a maximum at $620 \mathrm{~nm}$ (red curve in Figure 6a). In contrast, a fresh Fc solution only displays a shallow absorption band at 

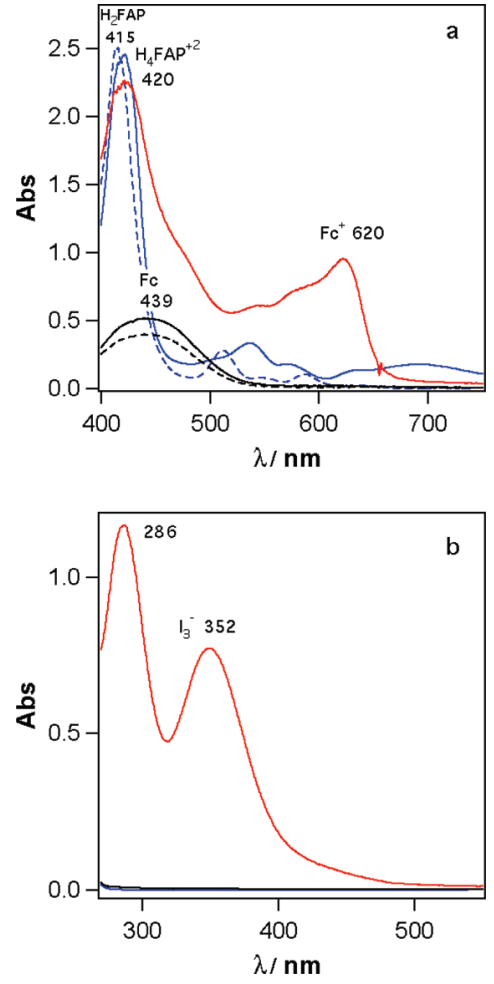

Figure 6. (a) UV-visible absorption spectra of the DCE phases separated from the flask 1 (black), flask 2 (red), and flask 3 (blue) after the twophase reaction illustrated in Figure 5a. The spectra of freshly prepared 5 $\mathrm{mM} \mathrm{Fc}$ (dotted black) and $30 \mu \mathrm{M} \mathrm{H}_{2} \mathrm{FAP}$ (dotted blue) are also displayed for comparison. (b) UV-visible spectra of the aqueous phases separated from the flask 1 (black), flask 2 (red), and flask 3 (blue) after treatment with an excess of NaI.

$439 \mathrm{~nm}$ (dotted black curve in Figure 6a). The formation of $\mathrm{Fc}^{+}$in the presence of only $\mathrm{Fc}$ in the DCE phase could not be observed (full black curve in Figure 6a). When only $\mathrm{H}_{2} \mathrm{FAP}$ is present in the DCE phase, protonation of $\mathrm{H}_{2} \mathrm{FAP}$ to form $\mathrm{H}_{4} \mathrm{FAP}^{2+}$ is clearly evidenced by the UV-visible spectral changes undergone by the Soret and Q bands (dotted blue curve shifted to the full blue curve in Figure 6a).

Addition of sodium iodide $(\mathrm{NaI})$ to the different aqueous phases was used to detect hydrogen peroxide by formation of tri-iodide, displaying two absorption bands at 286 and $352 \mathrm{~nm}$ as shown by the red curve in Figure $6 \mathrm{~b}$ for flask 2 . In contrast, no $\mathrm{H}_{2} \mathrm{O}_{2}$ was detected in flask 1 and flask 3 (blue and black curve in Figure $6 \mathrm{~b}$ ), indicating that $\mathrm{O}_{2}$ reduction in the presence of only $\mathrm{Fc}$ does not occur at this time scale. All these spectroscopic data suggest that $\mathrm{H}_{2} \mathrm{O}_{2}$ is formed during the biphasic reaction in the presence of both $\mathrm{Fc}$ and $\mathrm{H}_{2} \mathrm{FAP}$ in DCE.

To further prove these results, the titration of $\mathrm{H}_{4} \mathrm{FAP}^{2+}$ with $\mathrm{Fc}$ in DCE was performed, as shown in Figure 7. Adding Fc in large excess to a strongly acidic solution $\left(\mathrm{HClO}_{4}\right)$ of $\mathrm{H}_{2} \mathrm{FAP}$ resulted in the disappearance of the absorption features of $\mathrm{H}_{4} \mathrm{FAP}^{2+}$ and the appearance of those of $\mathrm{H}_{2} \mathrm{FAP}$, resolving the two broad $\mathrm{Q}$ bands at $\lambda_{\max }=505$ and $665 \mathrm{~nm}$ to four $\mathrm{Q}$ bands at $\lambda_{\max }=513,548,587$, and $644 \mathrm{~nm}$ and the blue shift of the Soret band from 419 to $415 \mathrm{~nm}$. This titration shows that $\mathrm{H}_{4} \mathrm{FAP}^{2+}$ catalyzes the oxygen reduction by $\mathrm{Fc}$ to generate $\mathrm{H}_{2} \mathrm{O}_{2}$, although this electron donor cannot reduce $\mathrm{O}_{2}$ directly even in the presence of an acid.

Finally, because it is experimentally difficult to follow the kinetics of ferrocene oxidation in the biphasic system due to the time required to separate the two phases, we have studied

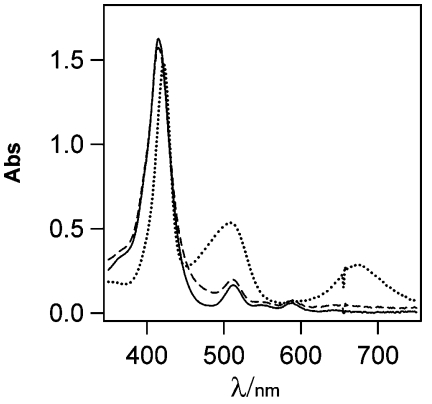

Figure 7. Absorption spectra of $20 \mu \mathrm{M} \mathrm{H}_{2} \mathrm{FAP}$ (full line), in the presence of $\mathrm{H}_{2} \mathrm{FAP}+20 \mathrm{mM} \mathrm{HClO}$ (dotted) and in the presence of $\mathrm{H}_{2} \mathrm{FAP}+20$ $\mathrm{mM} \mathrm{HClO}_{4}+1 \mathrm{mM} \mathrm{Fc}$ (dashed).

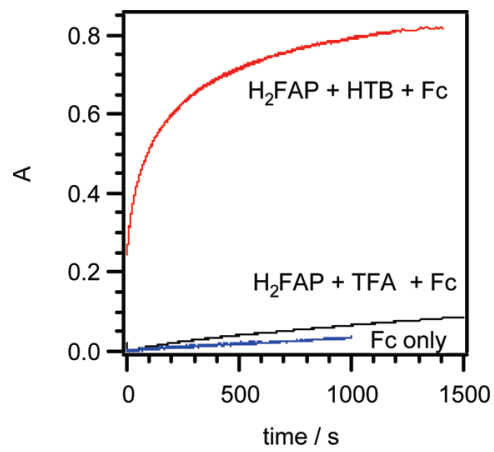

Figure 8. Absorbance at $\lambda=620 \mathrm{~nm}$ to monitor ferrocenium concentration. Initial conditions: 0 or $50 \mu \mathrm{M} \mathrm{H}_{2} \mathrm{FAP}, 2.12 \mathrm{mM}$ HTB as shown, $0.1 \mathrm{M}$ TFA as shown and $4.94 \mathrm{mM}$ ferrocene.

the reduction of oxygen in a single phase of DCE by ferrocene in the presence of HTB or TFA as acids and catalytic amounts of $\mathrm{H}_{2} \mathrm{FAP}$. The catalytic reaction was carried out using 4.94 $\mathrm{mM} \mathrm{Fc}, 50 \mu \mathrm{M} \mathrm{H} \mathrm{H}_{2} \mathrm{FAP}$, and $2.12 \mathrm{mM}$ of HTB or $0.1 \mathrm{M}$ TFA in a $\mathrm{O}_{2}$-saturated DCE solution. Figure 8 reproduces the absorbance changes at $620 \mathrm{~nm}$ (absorption band of $\mathrm{Fc}^{+}$) as a function of time. It clearly shows the catalytic role of $\mathrm{H}_{2} \mathrm{FAP}$ in the oxidation of ferrocene in the presence of oxygen and HTB as acid. In contrast, Figure 8 also evidence the absence of a catalytic effect when TFA is used instead of HTB or in the absence of porphyrin (Fc and HTB alone). These data prove that the catalytic reaction can only proceed through direct interaction of $\mathrm{O}_{2}$ with $\mathrm{H}_{4} \mathrm{FAP}^{2+}$ (vide infra). This can only happen if the counteranion does not interact with the protons inside the porphyrin core. In a solvent possessing a low dielectric constant such as 1,2-dichloroethane $(\varepsilon=10.42$ at $293 \mathrm{~K})$, one can logically expect an increased stability of ion pairs of the type $\mathrm{H}_{4} \mathrm{FAP} \cdots \mathrm{X}^{-}$( $\mathrm{X}^{-}$being a coordinating anion). Tetrakis(pentafluorophenyl)borate $\left(\mathrm{TB}^{-}\right)$is a noncoordinating anion compared to $\mathrm{CF}_{3} \mathrm{COO}^{-}$and should not interact with the inner protons. This assumption is further corroborated by marked differences in the Q-band region of the absorption spectra obtained by protonating $\mathrm{H}_{2}$ FAP either with $\mathrm{HTB}\left(\lambda_{\max }=544\right.$ $\mathrm{nm}, \varepsilon=8150 \mathrm{M}^{-1} \mathrm{~cm}^{-1} ; \lambda_{\max }=574 \mathrm{~nm}, \varepsilon=10900 \mathrm{M}^{-1} \mathrm{~cm}^{-1}$; $\left.\lambda_{\max }=628 \mathrm{~nm}, \varepsilon=5550 \mathrm{M}^{-1} \mathrm{~cm}^{-1}\right)$ or TFA $\left(\lambda_{\max }=579 \mathrm{~nm}\right.$, $\left.\varepsilon=11000 \mathrm{M}^{-1} \mathrm{~cm}^{-1} ; \lambda_{\max }=628 \mathrm{~nm}, \varepsilon=12900 \mathrm{M}^{-1} \mathrm{~cm}^{-1}\right)$. Moreover, a close examination of several X-ray crystal structures deposited in the Cambridge Structural Database (CCDC) for diprotonated free-base porphyrins with $\mathrm{CF}_{3} \mathrm{COO}^{-}$as counterions, clearly shows that for each structure the $\mathrm{CF}_{3} \mathrm{COO}^{-}$anions are interacting with the inner protons through $\mathrm{NH} \cdot \mathrm{OOCCF}_{3}$ 
Scheme 4. Structures of the $\left[\mathrm{H}_{3} \mathrm{FAP} \cdots \mathrm{O}_{2}\right]^{+}$(left) and $\left[\mathrm{H}_{4} \mathrm{FAP} \cdots \mathrm{O}_{2}\right]^{2+}$ Adducts; Unrestricted LMP2/cc-pVDZ Binding Energies at the M05-2X/ cc-pVDZ Optimized Geometries ${ }^{a}$
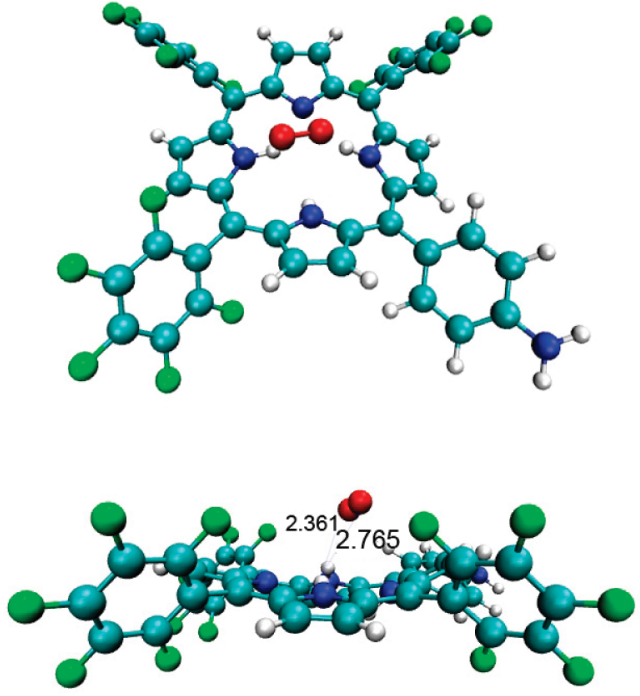

$3.77 \mathrm{kcal} / \mathrm{mol}(0.16 \mathrm{eV})$

${ }^{a}$ Closest $\mathrm{O}-\mathrm{H}$ distances are given in $\AA$.

hydrogen bonds $(\mathrm{H} \cdots \mathrm{O} \approx 1.9 \AA) .{ }^{33-38}$ Even though no X-ray crystal structure has been reported so far with $\mathrm{TB}^{-}$counteranions, Rayati et al. have described the structure of mesotetraphenylporphyrin protonated with tetrafluoroboric acid, $\mathrm{HBF}_{4}{ }^{39}$ Noteworthy, two water molecules are ligated to the inner protons of $\mathrm{H}_{4} \mathrm{TPP}^{2+}$ and further to the $\mathrm{BF}_{4}{ }^{-}$counterions but no direct interaction between the inner protons with $\mathrm{BF}_{4}{ }^{-}$ can be evidenced. In this report, the authors argue that fluorine is not efficient to induce hydrogen bonding simultaneously with the pair of inner protons of the porphyrin, although $\mathrm{F} \cdot \cdots \mathrm{H}$ bonds are generally stronger bonds than $\mathrm{O} \cdots \mathrm{H}$ ones. It is reasonable to assume a similar situation in the case of $\mathrm{TB}^{-}$anions. Therefore, by using HTB as the proton source in the catalytic experiments, the inner protons of $\mathrm{H}_{4} \mathrm{FAP}^{2+}$ are probably free for coordination of oxygen as shown below.

All the data presented above demonstrate unambiguously that $\mathrm{H}_{4} \mathrm{FAP}^{2+}$ can promote oxygen reduction by Fc. LMP2/cc-pVDZ single-point computations corroborates the formation of a triplet $\left[\mathrm{H}_{4} \mathrm{FAP}^{2+} \cdot \mathrm{O}_{2}\right]$ complex that is stabilized by $4.65 \mathrm{kcal} \cdot \mathrm{mol}^{-1}$ as compared to its separate adducts (i.e., triplet oxygen and $\left.\mathrm{H}_{4} \mathrm{FAP}^{2+}\right)$. $\left[\mathrm{H}_{3} \mathrm{FAP}^{+} \cdot \cdots \mathrm{O}_{2}\right]$ is slightly less stabilized (3.77 $\mathrm{kcal} \cdot \mathrm{mol}^{-1}$ in Scheme 4) and consequently expected to play a minor role in the catalytic activation of $\mathrm{O}_{2}$. The intramolecular production of $\mathrm{HO}_{2}{ }^{*}$ from the $\left[\mathrm{H}_{4} \mathrm{FAP}^{2+} \cdots \mathrm{O}_{2}\right]$ complex was found to be strongly disfavored. The data of Figure 7 show that we can globally describe the mechanism as:

(33) Berlicka, A.; Latos-Grazynski, L.; Lis, T. Inorg. Chem. 2005, 44, 4522.

(34) Bruckner, C.; Foss, P. C. D.; Sullivan, J. O.; Pelto, R.; Zeller, M.; Birge, R. R.; Crundwell, G. Phys. Chem. Chem. Phys. 2006, 8, 24022412 .

(35) Juillard, S.; Ferrand, Y.; Simonneaux, G.; Toupet, L. Tetrahedron 2005, 61, 3489-3495.

(36) Senge, M. O. Z. Naturforsch. B 2000, 55, 336-344.

(37) Senge, M. O.; Forsyth, T. P.; Nguyen, L. T.; Smith, K. M. Angew. Chem., Int. Ed. Engl. 1995, 33, 2485-2487.

(38) Senge, M. O.; Kalisch, W. W. Z. Naturforsch. B 1999, 54, 943-959.

(39) Rayati, S.; Zakavi, S.; Ghaemi, A.; Carroll, P. J. Tetrahedron Lett. 2008, 49, 664-667.
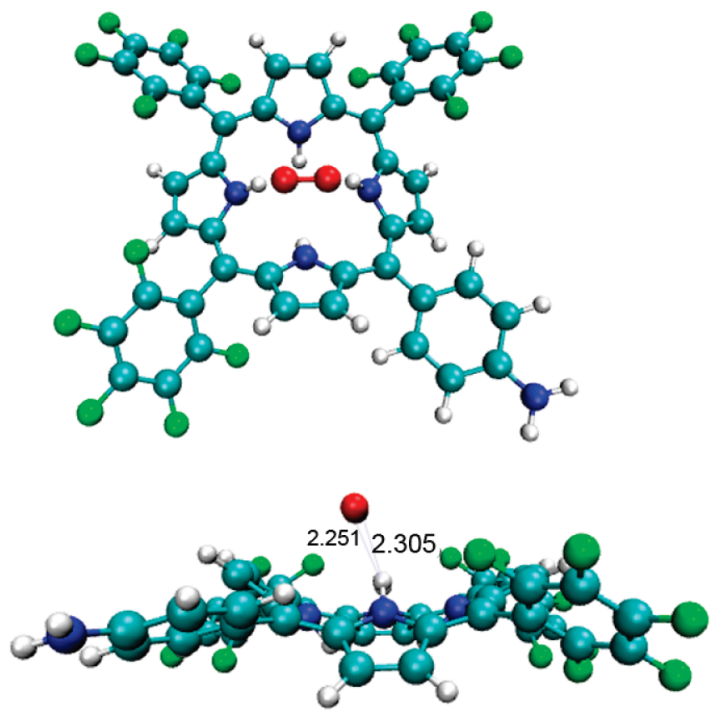

$4.65 \mathrm{kcal} / \mathrm{mol}(0.2 \mathrm{eV})$

$$
\begin{gathered}
\mathrm{H}_{4} \mathrm{FAP}^{2+}+\mathrm{O}_{2} \rightarrow\left[\mathrm{H}_{4} \mathrm{FAP}^{2+} \cdots \mathrm{O}_{2}\right] \\
{\left[\mathrm{H}_{4} \mathrm{FAP}^{2+} \cdots \mathrm{O}_{2}\right]+2 \mathrm{Fc} \rightarrow \mathrm{H}_{2} \mathrm{FAP}+\mathrm{H}_{2} \mathrm{O}_{2}+2 \mathrm{Fc}^{+}}
\end{gathered}
$$

The double proton coupled electron transfer reaction 6 is currently under study (see also Scheme 5). As shown in the Supporting Information (Figure S4), the oxidation potential of $\mathrm{H}_{2} \mathrm{FAP}$ is rather high for this molecule to operate as a redox catalyst.

\section{Conclusions}

The catalytic activation of the diprotonated form of a freebase porphyrin, 5-( $p$-aminophenyl)-10,15,20-tris(pentafluorophenyl)porphyrin $\left(\mathrm{H}_{2} \mathrm{FAP}\right)$, on the molecular oxygen $\left(\mathrm{O}_{2}\right)$ reduction by ferrocene $(\mathrm{Fc})$ has been investigated at the polarized water/ 1,2-dichloroethane (DCE) interface. Ion-transfer voltammetry has revealed that $\mathrm{H}_{2} \mathrm{FAP}$ can assist a double proton transfer from water to DCE by the formation of $\mathrm{H}_{4} \mathrm{FAP}^{2+}$ in DCE, which thereby activates $\mathrm{O}_{2}$ reduction by Fc. The catalytic role has been verified by using a weak reductant, ferrocene $(\mathrm{Fc})$ that is quasiinert to $\mathrm{O}_{2}$ in the absence of a catalyst. Two-phase reactions with the Galvani potential difference between the two phases

Scheme 5. Mechanism of $\mathrm{O}_{2}$ Reduction with Fc Catalyzed by $\mathrm{H}_{2} \mathrm{FAP}$

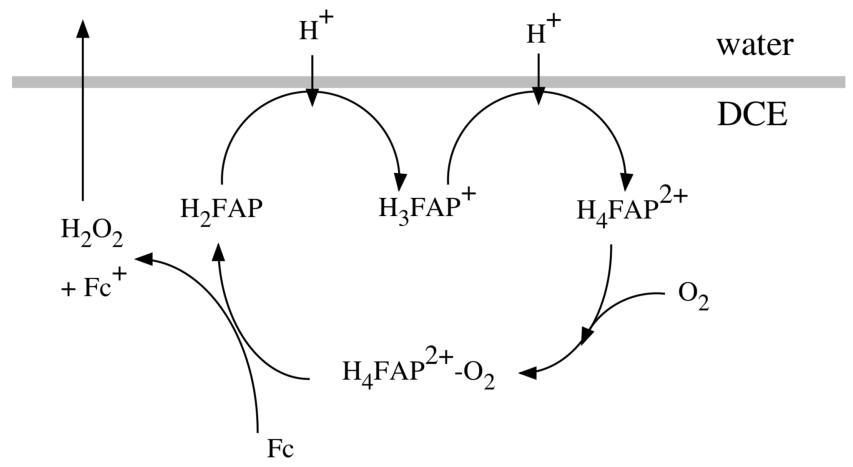


controlled by a common ion partition were performed, which not only prove the catalytic activation of $\mathrm{H}_{4} \mathrm{FAP}^{2+}$ on $\mathrm{O}_{2}$ reduction but also suggest a two-electron reduction pathway to produce $\mathrm{H}_{2} \mathrm{O}_{2}$.

Acknowledgment. This work was supported by Ecole Polytechnique Fédérale de Lausanne (EPFL), European Cooperation in the field of Scientific and Technical Research (COST Action, D36/ 007/06), the Centre National de la Recherche Scientifique (CNRS, UMR 5260), the Agence Nationale pour la Recherche (ANR project "Chelan"), Grant Agency of the Czech Republic (no. 203/07/1257).
I. H. also gratefully acknowledges the Scientific and Research Council of Turkey (TUBITAK). C.C. thanks Stephan N. Steinmann for the single point computations within Q-Chem.

Supporting Information Available: Complete refs 26 and 29, synthetic and characterization details of $\mathrm{H}_{2} \mathrm{FAP}$, Cartesian coordinates of the M05-2X/cc-pVDZ optimized geometries, and electrochemistry data. This material is available free of charge via the Internet at http://pubs.acs.org.

JA103460P 